\title{
Slavic and East European Language Programs and Heritage Language Communities
}

\author{
Susan Kresin \\ University of California, Los Angeles
}

\begin{abstract}
Among Slavic and East European heritage communities, the post-1989 geopolitical situation in Central and Eastern Europe has changed both emigration patterns and core aspects of the relationship between speakers in the homeland and abroad. Many speakers have both an enhanced motivation to maintain their heritage languages and greater resources to do so. As a reflection of this increased interest in Slavic and East European heritage languages, recent years have witnessed a rise in the number and scope of community language schools, established primarily by parents who wish to ensure that their children maintain active use of their heritage languages. At the same time, many Slavic and East European language programs at the college level have increasingly come under threat, due to the combination of reduced enrollments, greater administrative focus on class sizes, and a loss of federal funding. In this paper, using Czech as the base language, I suggest that by placing a greater emphasis on connections with heritage communities, we may be able to enhance the viability of Slavic and East European programs at the college level. This potential is supported by a marked increase in research on heritage language learners over the past two decades, which provides a foundation for curricular adjustments that address the specific needs of heritage language learners.
\end{abstract}

Keywords: heritage language, Slavic LCTLs, Slavic languages, West Slavic.

W

ith increased globalization in the twenty-first century, a new type of international mobility has emerged: in contrast to the previous pattern of emigration from Slavic and East European countries as a one-way and terminal departure from the home country, newly arriving speakers are often "transnational," interconnected in various ways with more than one national space. In her dissertation on Czech and Slovak heritage communities in the Southeastern United States, McCabe notes that

[as] a consequence of globalization, contemporary migrants are equipped with resources, such as communication and information technologies and affordable transportation, that allow them to stay involved in their homeland socially, politically, and economically while residing elsewhere, to maintain transnational familial relationships, and to develop unique transnational identities. (70) 
This wave of "transnational" speakers has access to a variety of technologies that greatly facilitate language maintenance and connectedness with the home country, such as Internet-based resources and free or inexpensive long-distance communication systems. Many take their children to the home country for extended summer visits and/or have grandparents living with them for extensive periods of time to help with childcare, especially during the children's preschool years, and many are highly educated professionals who leave the home country in connection with career opportunities (Dubinina and Polinsky 2; McCabe 59; Petrescu 23). Those who plan to return to the home country have both an enhanced motivation to maintain their heritage languages and greater resources to do so than in the past.

Reflecting this interest, in recent years the number and scope of community schools providing heritage language instruction has increased. For Czech language instruction, a network of schools called "Česká škola bez hranic" (Czech School Without Borders) was initiated in Paris in 2003 and has since spread to seven other European cities (Česká škola; "Ve světě roste"). These schools aim to provide Czech children with educational opportunities that are directly parallel to the home country curriculum, to enable them to integrate into Czech schools when their parents' jobs take them back to the Czech Republic. In North America, in addition to previously existing community schools in traditional emigrant areas such as Chicago and Toronto, new community schools have opened since 2010 in Atlanta, Dallas, Durham (North Carolina), Los Angeles, San Diego, the San Francisco Bay Area, Seattle, and other locations.

In her survey of Czech and Slovak families' motivations, McCabe found that parents of heritage language speakers associated three primary goals with language maintenance: 1) communication with family members and other people in their home country, 2) instilling in their children a sense of "cultural heritage and ethnic identity," and 3) "academic, cognitive and social benefits" that derive both from learning the heritage language itself and, more generally, from the study of a second language from an early age (10644). One parent that McCabe interviewed summed up her goals as follows:

We would like our children to be able to talk to their grandparents and other Czech relatives, and understand the culture of their ancestors. I do believe it is important for them to define who they are and where they came from. Speaking more than one language helps the children better understand the world in general and it also opens more opportunities. (109)

These goals reflect an interweaving of integrative and instrumental motivations (Gardner 50-56, 62-83; Geisherik, "The Role of Motivation" 10). First and foremost, the parents surveyed wanted their children to internalize 
a sense of their ethnic heritage and to be able to integrate to some degree within the society of their country of origin. At the same time, they viewed acquisition of the heritage language as an asset in their children's overall development: they expected their children to derive long-term cognitive and career-oriented benefits from learning a second language from an early age. ${ }^{1}$ Nevertheless, none of the families in McCabe's study expected their children to be able to use Czech or Slovak professionally, due to the relatively small global applicability of these languages. Therefore, these families focused their efforts primarily on oral skills, for direct interpersonal communication with family and others in the home country (McCabe 126).

At the same time as heritage communities are demonstrating an enhanced and more personally invested interest in heritage languages, home country attitudes are shifting toward growing appreciation of the cultural, social, political, and economic benefits that collaboration with the diaspora can offer. For example, the Czech Ministry of Foreign Affairs now devotes a special branch to supporting relations with the diaspora, providing financial and other support for a variety of educational initiatives at various age levels ("Krajané"). Since 2011, it has supported an annual conference of Czech community school instructors ("Podpora"). The Charles University Institute for Language and Preparatory Studies (ÚJOP) offers a four-week summer course designed specifically for adult "krajané" (compatriots; "Kurz češtiny"). In addition, Czech Television is currently developing a series of movies titled České kořeny (Czech Roots), aiming to familiarize viewers in the Czech Republic with communities of Czech heritage around the world. All of these initiatives reflect and support the new wave of globally connected, transnational heritage communities.

\section{HERITAge LANGUAGE LEARNERS AND ColLEgE-LEVEL LANGUAgE COURSES}

At the same time as globalization has enabled enhanced contacts between heritage communities and home countries, it has also intensified pressures on college-level language programs associated with smaller home-country

1 This combination of heritage-based and external motivation may reflect the publicity in recent years on the cognitive benefits of bilingualism: early acquired knowledge of a heritage language is viewed not only for its intrinsic benefits but also as a source of cognitive enhancement in a child's development, and as a gateway for later study of languages with greater global applications. See also Bialystok and Petrescu. 
populations. In the globalized world, knowledge of certain languages can be viewed not only as a reflection of ethnic and cultural identity, but also as a commodity, a marketable asset that can enhance professional and economic opportunities (Heller 474). This factor favours languages that are associated with business opportunities, such as Chinese and Spanish (Carreira and Kagan 48, 51,52), but disfavours languages associated with smaller global markets, especially in periods of economic downturn and high unemployment rates, when many students take a more pragmatic view of their studies and choose their courses with an eye to opportunities for career enhancement. According to a survey recently conducted by the Modern Language Association, after a period of rising enrollments in the early years of the twenty-first century, we are currently in a period of decline in the less commonly taught languages, taken as a whole ("Language Enrollment Database"; "Enrollments in Languages"). Combined with increased administrative pressures to maintain enrollment figures, as well as elimination of federal funding that was provided during the years of the Cold War, and new alternatives to past requirements that graduate students in Slavic departments take a second Slavic language, many language programs are under threat of closure. This makes it a particularly important time to cultivate ties with heritage communities and to collaborate with them in their efforts to promote language maintenance. Anecdotally, some programs have noted an increased percentage of heritage language students in recent years, ${ }^{2}$ a trend that may continue as more children from the post- 1989 wave of migration from Central and East European countries reach college age. ${ }^{3}$

A number of studies have noted a tendency for many students to choose a foreign language to study in college on the basis of a "heritage affiliation with the language and culture" (Murphy et al. 45; see also Brown; Carreira and Kagan; Geisherik; Howard et al.; Kagan and Kresin; Lauersdorf; Liu and Shibata; and Seymour-Jorn). Heritage affiliation is cited in these studies as an especially compelling reason among those students who take languages other than French, German, Italian, and Spanish. Many students have mixed heritage; for example, of eleven students enrolled in Introductory Czech at UCLA in the academic year 2007-08, five had a partial Czech heritage

2 Fidler, Masako. Personal interview. 29 June 2016; Langer, Ellen. Personal interview. 29 June 2016.

${ }^{3}$ McCabe notes a sixfold increase from 1987 to 2001 in the number of Central and East European immigrants admitted to the United States with legal permanent residency. 
(ranging from one-half to one-eighth). One of these students, who did not grow up with Czech spoken in his home, noted: "I feel a strong desire to reconnect with that part of my family. I feel that our family had lost a piece of its heritage when the language wasn't passed on" (Kagan and Kresin 116). Murphy and others found heritage affiliation to be especially relevant for students who continue their language study beyond introductory levels (55). ${ }^{4}$ Supporting this finding, over the past ten years half or more of the students in advanced tutorial courses offered in Bosnian-Croatian-Serbian [BCS], Czech, and Romanian at UCLA have had a heritage motivation. ${ }^{5}$

Likewise, in a survey conducted by the National Heritage Language Resource Center of students taking university-level courses as heritage language learners, the majority of the respondents indicated that they considered themselves "hyphenated Americans or Americans with a dual identity (for example, Vietnamese-American, American Vietnamese, etc.; Kagan, "Intercultural Competence" 73). While the less commonly taught Slavic and East European languages were not included in the survey, comments in follow-up interviews by heritage speakers of Russian often reflected a sense of an "intercultural space," as in the following:

1. "I think I consider myself an American. I am an American with Russian roots" (four years old at immigration);

2. "Most likely I am a Russian American. I feel that I am American but I am from Europe" (6.5 years old at immigration);

3. "In general, I am Russian. I am an American in my daily life, but I am Russian" (seven years old at immigration; Kagan, "Intercultural Competence" 74).

While many of these students had the option of fulfilling their language requirement by continuing their high school study of languages such as Spanish or French, when given the opportunity, they opted for the more personalized pathway of studying their heritage language.

\footnotetext{
${ }^{4}$ Murphy and others surveyed 2,819 students. Among the Slavic languages, Polish, Russian, and Serbo-Croatian were included in the survey.

5 Galateanu, Georgiana. Personal interview. 29 June 2016; Lejko-Lacan, Viktorija. Personal interview. 30 June 2016.
} 


\section{RESEARCH AND OTHER SUPPORT FOR TEACHING HERITAGE LANGUAGES}

Academic interest in heritage languages has also increased dramatically over the past two decades. New institutional support includes the Alliance for the Advancement of Heritage Languages (est. 2002), the Centre for Diaspora and Transnational Studies (CDTS) at the University of Toronto (est. 2005), and the National Heritage Language Resource Center at the University of California Los Angeles (est. 2006), which publishes Heritage Language Journal. ${ }^{6}$ Since 2000, over forty languages have been represented in nearly three hundred North American doctoral dissertations focusing on heritage themes, reflecting the growth of heritage studies as an academic field (Seals et al., "Dissertations with Heritage"). Slavic and East European languages addressed in these dissertations include Czech, Polish, Romanian, Russian, Slovak, Ukrainian, and the Balkan languages in aggregate. ${ }^{7}$ These new studies have facilitated a deeper understanding of the specific abilities and motivations of heritage language learners, and the development of new methodologies and courses specifically oriented to their needs. Separate tracks for heritage and non-heritage students are now common in Spanish, and a number of universities offer specialized courses for students of Arabic, Chinese, Hindi, Italian, Japanese, Korean, Polish, Russian, and Vietnamese heritage (Kondo-Brown; Beaudrie et al.). Developing on the perspective that in the globalized world advanced language speakers can be a valuable national resource (Brecht and Ingold; Brecht and Rivers; Eisen), the government-sponsored StarTalk program and the National Heritage Language Resource Center support summer courses for high school heritage students in Armenian, Japanese, Korean, Persian, Russian, and other languages. While the less commonly taught Slavic and East European languages lack the financial backing enjoyed by languages such as Persian and Russian that are deemed "critical" for national security, similar programs have increasingly emerged in heritage communities. An example is the newly

${ }^{6}$ See Lynch for an overview of articles published in Heritage Language Journal in the first decade of its existence, 2004-14. For a broader review of research on heritage language issues, see Van Deusen-Scholl.

${ }^{7}$ For Czech and Slovak: McCabe; for Polish: Barski; for Romanian: Petrescu; and for Russian: Bain, Dengub, Dubinina, Geisherik, Karkafi, Kasatkina, Kradinova, Laleko, Lyutykh, Mikhaylova, Moore Language and Social Identity, and Smyslova Developing Four-Skill Literacy; for Ukrainian: Seals; and for Balkan languages: Jevgjovikj. For Lithuanian, see also Tamošiūnaitè; and for Hungarian, see also Fenyvesi. 
established Czech Summer School for Children at the T.G. Masaryk School in Chicago, created in collaboration with colleagues at Charles University in Prague. Support for developing this type of program is provided by extensive research on various types of community language schools, teacher training (Caballero; Moore, "Program Models"; Potowski et al.; Lui et al.; Van DeusenScholl), and practically oriented workshops for heritage language teachers, both in person and online ("Teaching Heritage Languages").

\section{FEATURES OF HERITAGE LANGUAGE LEARNERS}

As many studies have shown, students of heritage languages tend to have a wide range of abilities (Benmanoun et al.; Carreira and Kagan; Isurin and Ivanova-Sullivan; Polinsky and Kagan; Polinsky, "Heritages Languages"; Tamošiūnaitè). However, some common trends can be identified. This section focuses on these trends and outlines some pedagogical consequences.

First, as a result of growing up in multilingual homes where they hear the heritage language spoken by family members and are exposed to their heritage language culture, heritage speakers tend to have stronger receptive skills than productive skills: they can understand more complex language than they can actively produce. Even students who cannot speak at all may have active listening skills, and, as opposed to L2 learners, their exposure to language does not take place in distinct segments (as individual words or phrases), but in connected discourse. Therefore, many researchers advocate a "top-down" approach for heritage language learners, basing assignments on full texts (written or oral), rather than initially focusing on individual language forms (Kagan and Dillon; Chevalier, Carreira and Kagan; Beaudrie et al.). In addition, heritage students can apply their foundation in the home language to learn to speak, read, and write more quickly than typical L2 learners (Smyslova, "Low Proficiency"). In programs without heritage tracks, this necessitates flexibility in placement decisions, as a heritage student who initially lacks the literacy skills expected for intermediate-level L2 placement can soon become bored in introductory classes.

Second, since heritage speakers are typically immersed in an environment where another language is dominant for many of their "prime language-learning years" and in most educational settings, their range of linguistic and social experiences in the heritage language tends to be limited (Beaudrie et al.). As Valdés notes, "because the two languages play different roles and are used in different ways, each of the languages develops different strengths" (383). In the heritage language, they tend to be high functioning in interpersonal modes, particularly informal speech on topics relating to 
home life. They tend to be more limited in interpretative and presentational modes, which are more typically associated with formal education (Angelelli and Kagan 198). Even heritage students who may seem fluent in the spoken language can benefit from academic language courses, because their "home culture ... differs greatly from the academic culture in which they find themselves upon entering college." They tend to have "little to no experience with the academic register" and a correspondingly "limited grasp of appropriate academic vocabulary, and difficulty in forming complex sentences" (Friedman and Kagan 183). Reflecting the primary role of the heritage language in informal settings, the speech of heritage learners is often restricted to short sentences and simple conjunctions (parataxis). Their lack of sustained experience in academic contexts in the heritage language is also reflected in their minimal use of participles, gerunds, relative clauses, and complex temporal and causal connectors (Bermel and Kagan; Isurin and Ivanova-Sullivan; Laleko). However, they are likely to have an active command of academic language in their dominant language, which can provide models for use in the heritage language.

Third, bilingualism is a "dynamic condition" that can change over the course of a person's lifetime (Valdés 385). A person's active use of the heritage language may vary extensively over the years of childhood. This can lead to different levels of retention at different ages, as well as more active acquisition of features associated with certain times in childhood. For example, Polinsky notes that diminutive forms are often overused in heritage Russian, in ways that can comically contradict age-appropriate conventions, but are a natural outcome of their high frequency in the language of early childhood, the main period of active acquisition for many heritage speakers ("Incomplete Acquisition"). For many speakers, the influence of the heritage language diminishes in later childhood, with less active use and/or exposure in middle and high school. Consequently, their speech in the heritage language may not reflect the cognitive and social development that takes place during this later age span. They may also have a sense of having lost a language that once came easily to them, as well as a connection to a culture that was previously a more dominant part of their lives.

A fourth feature of the language of heritage speakers is that it typically reflects not only incomplete acquisition, but also the influence of the dominant language. Code-switching, borrowings, and extensions of meaning are common, with heritage speakers frequently borrowing, extending, and blending not only lexical items, but also grammatical conceptualizations and pragmatic conventions (on Polish, see Barski; on Russian, see Benmanoun et al.; Dubinina; Dubinina and Polinsky; Isurin and Ivanova-Sullivan; Kagan, "Intercultural Competence"; Laleko; Pavlenko; Polinsky, "Cross-Linguistic Parallels", "Incomplete Acquisition", "Russian Gender"; Zemskaja and 
Glovinskaja; and on Czech, see Henzl). Grammatical categorizations tend to be simplified or otherwise reanalyzed if not supported by parallel categorizations in the dominant language. For example, heritage speakers living in English-speaking countries tend to have a highly reduced case system, if any (on Croatian, see Albijanić, Gasiński; on Czech, see Henzl; on Hungarian, see de Groot; on Polish, see Lyskawa; Preston and Turner; on Russian, see Isurin and Ivanova-Sullivan; Laleko; Leisiö; and Polinsky, "Incomplete Acquisition"; and on Slovene, see Paternost). They tend, moreover to have aspectual systems with a simplified, largely lexical basis rather than as a full-fledged grammatical category (on Russian, see Gagarina; Laleko; Mikhaylova; Pereltsvaig; Polinsky, "Incomplete Acquisition"; and Stoll; on Bulgarian, see Kuehnast; and on Polish, see Weist et al.). However, their experience hearing the fuller system of native speakers in their home life enables them to understand authentic texts with the correct forms, a fact that further reinforces the effectiveness of a "top-down" approach in which models of the fully native system are presented in engaging contexts.

Finally, since the primary language input is likely to be the spoken variant or dialect used at home, the baseline language of heritage learners is not necessarily the standardized literary language that is typically taught and favoured in foreign language classes (Kramer; Pires and Rothman; Polinsky, "Heritages Languages"; Polinsky and Kagan; Sussex). This is an especially important factor in languages with strong differences between the literary and colloquial variants, such as Czech (Čmejrková et al.; Hronek; Townsend), or with a range of dialects (see Kramer on the challenges of teaching Macedonian). Assessments such as online placement tests that admit only the standard literary variant may severely under-report a heritage student's functional abilities (Kagan, "In Support"; Malone et al.), and form-based criteria in assigning grades may need some adjustment from the standard L2 rubrics. In addition, many heritage language speakers grow up hearing primarily the language of their parents and other adults, which may be marked with generational features. Given the major societal changes over the past twenty-five years in Central and Eastern Europe, with correspondingly significant and rapid language shifts, for Slavic and East European heritage language learners the language spoken at home may be dated or even archaic relative to the contemporary language of the home country.

\section{PEDAGOGiCAL CONSEQUENCES}

The literature on heritage language instruction identifies seven main goals:

1. Language maintenance. 
2. Acquisition or development of a prestige language variety.

3. Expansion of the bilingual range.

4. Transfer of literacy skills.

5. Acquisition or development of academic skills in the heritage language.

6. Positive attitudes toward both the heritage language and various dialects of the language and its culture and subcultures.

7. Acquisition or development of cultural awareness (Beaudrie et al. 59; Valdés).

While these goals overlap with the goals of L2 instruction, certain adjustments are necessary to meet the specific needs of heritage language learners. This section shows how, using the same core materials, instructors can differentiate students' learning processes, materials, and output, tailoring instruction to individual students' abilities, interests, and needs (Blaz; Gregory and Chapman; Tomlinson). Since Slavic and East European language classes as a whole tend to have not only relatively small enrollments, but also students with a wide range of abilities, interests, and goals (Lauersdorf), differentiation must be a core feature of any curriculum in these languages. Certain modalities and types of assignments are especially well suited for differentiation in mixed heritage-L2 classes.

Given the relatively strong listening skills of heritage speakers, a mixture of text types on a single topic, from both print and orally based sources, can be particularly useful for mixed heritage-L2 classes. For example, even in beginning language courses students of all backgrounds can cull basic information from brief written biographies by focusing on names, locations, dates, and cognates. The written form enables L2 learners to identify proper nouns and numbers far more easily than they could in an oral text. Heritage students can extend this fact-finding task to a higher level, even with minimal literacy, by applying their oral comprehension skills to viewing television documentaries. For Czech classes, the Největši Čech ("The Greatest Czech") project of Česká televize is especially useful for this type of assignment, as for each of the top ten candidates, it includes a brief "medallion" biography, a biography in dates, a question-and-answer "chat" with a well-known advocate for the given candidate, and a forty-minute television documentary. The combination of various text types and registers, as well as content of varying complexity, enables heritage language students to build on their foundational skills while expanding both their linguistic abilities and their core cultural knowledge. 
Both heritage and L2 students tend to enjoy film assignments, and given their relatively strong listening skills and cultural grounding, heritage language learners are often able to understand the language and cultural background of movies much more easily than L2 learners. With technological advances that make media more accessible for individual viewing (including restricted course websites), movies in mixed classes can be viewed independently with a variety of levels of scaffolding: introductory L2 learners can view the movie with English language subtitles, while heritage students can use heritage language subtitles (captions), no subtitles, or a combination of these three options, as needed. Depending on the level of the specific students, Beaudrie and others, following Carreira and Kagan, suggest the following activities for heritage language students:

1. Discuss or debate interesting themes in the movie.

2. Transcribe lines or write a description of a scene from the movie (individually or in groups).

3. Write an analysis or evaluation of the movie.

4. Evaluate pieces of dialogue as either formal or informal registers; convert one to the other. (71)

Many heritage language students have had experience viewing movies from their heritage culture in their home life, and these tasks build on this familiarity while transferring and developing cognitive and academic skills that they have acquired through schooling in their dominant language. Some of these activities, such as debate and analysis, require high levels of language ability, but they can be scaffolded for heritage groups with various types of authentic texts, such as movie reviews and interviews with directors or actors, which build on heritage learners' relatively strong receptive skills and provide models. Movie scripts can be used and adapted in various ways, including performance of individual scenes, full or partial transcription, creating stylistically appropriate subtitles (Kagan, "Russian Heritage"), comparing passages of films adapted from novels with excerpts from the source novels (Janda), and creating variants. While engaging students in the target language culture, these assignments both support comprehension for the class as a whole and help heritage students transfer their oral skills to reading and writing. ${ }^{8}$

8 For Czech, a number of scripts and exercises created by Steven Clancy, David Danaher, Masako Fidler, and Laura Janda are available at the SEELRC "Czech 
Independent research projects and presentations are valuable for all students, providing opportunities for heritage language students to extend their abilities to the interpretive and presentational modes in academic registers. Research projects contribute to students' information literacy in the heritage target language, by acquainting them with online and other resources, and therefore enhance their ability to become independent and long-term users of the language, beyond the confines of the specific class. Having students conduct independent research with multiple print and oral sources on a single topic creates "islands" of higher-level competence within the students' specific fields of interest (Shtekhman and Leaver), scaffolding their development toward more advanced levels. While research presentations in mixed-level classes can be problematic for students with lower levels of listening skills, presentation software like PowerPoint or Prezi facilitates visual and/or dual language scaffolding. Structuring PowerPoint slides with a question-and-answer format (with the question as the header and the answer in the body of the slide) further facilitates comprehension in classes with mixed oral abilities: the questions identify the informational goal of each slide, as a preview to the information itself.

In mixed heritage-L2 classes, heritage students also benefit from independent reading, both in connection with research projects and as an end in itself. The benefits of "free voluntary reading" in heritage language programs have been well-documented by McQuillian, Krashen, and others, especially when students engage in "narrow reading" of several texts on a single topic, which enables them to develop background knowledge and topic-specific vocabulary. The Brown University On-Line Czech Literary Anthology is an invaluable source for launching heritage students of Czech into independent reading, as it includes recordings of each text, enabling them to build on their oral skills as they learn to read relatively complex written texts. Glosses and cultural annotations further support independent and student-selected reading. For in-class dramatic reading with pairs or small groups of heritage students, ${ }^{9}$ the one-act Vania plays by Václav Havel have been especially successful in Czech classes at UCLA: repetition in the

Webliography" site for teachers of Czech: http://www.seelrc.org/lmwczech/teacher_materials/teacher_directory.htm.

Additional glossed and annotated scripts are provided at http://cokdybysme.net/syllabimaterials.html.

${ }^{9}$ Or in mixed groups with other students who have similarly advanced skills, such as graduate students with prior knowledge of Russian. 
style of absurdist theatre facilitates comprehension, and the plays serve as a springboard for students to explore stylistic variation and the pragmatic effect of using various registers in different contexts (see Danaher).

Assignments using contemporary media, both written and spoken, tend to be of interest to both heritage language and L2 learners, and they help to acquaint heritage students with current language norms as well as linguistic variations. Janda offers a framework for incorporating news articles on current events into the curriculum, using student-selected vocabulary lists and summaries. When her students did brief weekly assignments of this type, they found predictable lexical and grammatical patterns that enabled them to become independent users of news media. Evans-Romaine and others suggest ways to build both literacy and cultural grounding through assignments involving songs and song lyrics. WebQuests, an inquiry-based learning activity grounded in the Internet, are also well-suited to language classes with mixed heritage and non-heritage enrollment, as they can accommodate a wide range of interests and abilities within a single overarching assignment. Typically, WebQuests involve a goal-oriented task and proceed in clearly defined steps, with information sought on the Internet and then integrated into a classroom and/or written activity. ${ }^{10}$ Students can be given specific roles to research, either alone or with a partner. For example, in a sample travel assignment available on a WebQuest database, students choose a destination city and a researcher role: "transportation manager," "sightseeing manager," "entertainment manager," or "food and accommodations manager" (Deligiannidou). The students each research a different aspect of travel to one of two cities, using specific web links suggested by the instructor, and then integrate their findings into an itinerary. Instructors can adapt the suggested resources to a range of student ability levels, with various combinations of written and video materials and texts of varying complexity. For this type of assignment, heritage students can also tap their resources in the target language community, for example, by interviewing or polling native speakers, including relatives and friends in the target language country via Skype or chat groups. They can also play a "debriefing" role, researching cultural differences that may be relevant for travellers (for example, tipping behaviour, how to dress for different types of

${ }^{10}$ Nemtchinova presents an overview of the goals and methodology of WebQuests and documents positive student attitudes towards WebQuests, especially as a means for developing target language information literacy skills and cultural and lexical competence. 
cultural performances, or how to ask for information and make requests in culturally appropriate ways). ${ }^{11}$ Other existing WebQuests that can easily be adapted for heritage language classes include "A Trip to Prague" (Slegrova); "A Pirate on the Danube," which models using a story line as the basis for seeking historical and cultural information; "Around the World in Chicago" ("Around the World"), which models explorations into heritage communities; and "Across the Barricades" (Marteijn et al.), which demonstrates how students can independently research a historical event that plays a key role in a work of literature.

Finally, heritage and non-heritage students can work together in pairs or small groups in various types of ventures into heritage communities, tapping the heritage students' superior oral skills while connecting all students with the culture and customs of the local heritage community. Curricularly grounded connections with the heritage community can be as straightforward as ordering dinner in the target language at an ethnic restaurant or making a purchase at an ethnic store, or it can involve more complex planning, as in situations of volunteering or interviewing community members. Heritage speakers are accustomed to patterns of ellipsis, unfinished sentences, and false starts that are typical of natural spoken language, and they can help their L2 classmates learn to cope with these real-life speech patterns, which are rarely encountered in the language of textbooks and other instructional materials. All students can benefit from exposure to the range of dialects, ideolects, and stylistic variants that coexist in a heritage language community. At the same time, interacting with unfamiliar members of heritage communities provides a motivated context for heritage learners to practice more formal oral language than they typically use in their home environment, including not only polite/formal forms of address and greetings, but also a wider range of vocabulary and, in some situations, relatively complex sentence structures. For assignments involving interviewing, Kagan emphasizes the need to be proactive in preparing students to interact with speakers in heritage communities, by teaching them appropriate pragmatic knowledge, interaction strategies, and interviewing techniques; in research projects, students may also need instruction in analyzing the data provided in community speakers' responses

11 Dubinina and Polinsky found that even high-functioning heritage language speakers tend to lack full pragmatic competence, using English-language models when performing tasks such as requesting favours. Heritage language students with transnational connections are in a unique position to conduct polls on pragmatic preferences of this type. 
and in soliciting follow-up information ("Russian Heritage"). Nyikos and Dimitrieska propose a highly innovative model for involving university students in teaching language to young learners. This connection with their "past selves" in heritage communities could be particularly motivating and personally rewarding for heritage language learners.

All of these of activities build on the typical strengths of heritage students, while challenging them to expand their linguistic breadth and stylistic range. They build on the heritage motivation that many students bring to foreign language study, and give them individualized opportunities to deepen their knowledge of their ethnic heritage within the broader L2 curriculum.

\section{CONCLUSION}

As this study has shown, a number of circumstances combine to make this a felicitous time for connections between college-level language programs and Slavic and East European heritage language communities. First, reflecting the new geopolitical situation of the post-Communist, globalized world, many first and second generation speakers remain closely connected to the home country. This enhances their motivation to maintain their heritage languages. Second, these transnational contacts are supported by both technological advances and the growing network of community language schools, which provide them with more opportunities to maintain their heritage languages more easily than in the past. Third, the marked increase in research on heritage language topics over the past ten years provides a solid foundation for understanding the specific needs of heritage language learners. Using a variety of resources and task types to differentiate instruction, language instructors can meet the challenges of teaching mixed heritage and nonheritage language classes in engaging and motivating ways.

\section{Works Cited}

Albijanić, Aleksandar. "San Pedro Revisited: Language Maintenance in the San Pedro Yugoslav Community." The Slavic Languages in Émigré Communities, edited by Roland Sussex, Linguistic Research Inc., 1982, pp. 11-22.

Angelelli, Claudia, and Olga Kagan. "Heritage Speakers as Learners at the Superior Level: Differences and Similarities Between Spanish and Russian Student Populations." Developing Professional-Level Language Proficiency, edited by Betty Lou Leaver and Boris Shekhtman, Cambridge UP, 2002, pp. 197-218.

"Around the World in Chicago." Questgarden, questgarden.com/81/31/2/ 090423144150/process.htm. Accessed 7 Oct. 2016. 
Bain, Sharon. "Preserving Heritage Languages As a Viable Resource in the United States: Assessment of the Russian Language Environment in Philadelphia." Dissertation, Bryn Mawr College, 2004.

Barski, Ewelina. "Spanish and Polish Heritage Speakers in Canada: The Overt Pronoun Constraint." Dissertation, University of Western Ontario, 2013.

Beaudrie, Sara. "Research on University-Based Spanish Heritage Language Programs in the United States: The Current State of Affairs." Spanish as a Heritage Language in the United States: State of the Field, edited by Sara Beaudrie and Marta Fairclough, Georgetown UP, 2012, pp. 203-21.

Beaudrie, Sara, et al. Heritage Language Teaching. McGraw Hill, 2015.

Benmamoun, Ellabas, et al. "Heritage Languages and Their Speakers: Opportunities and Challenges for Linguistics." Theoretical Linguistics, vol. 39, no. 3-4, 2013, pp. 129-81.

Bermel, Neil, and Olga Kagan. "The Maintenance of Written Russian in Heritage Speakers." The Learning and Teaching of Slavic Languages and Cultures, edited by Olga Kagan and Benjamin Rifkin, Slavica, 2000, pp. 405-36.

Bialystok, Ellen. Bilingualism in Development: Language, Literacy, and Cognition. Cambridge UP, 2001.

Blaz, Deborah. Differentiated Instruction: A Guide for Foreign Language Teacher. Eye on Education, 2006.

Brecht, Richard, and Catherine Ingold. Tapping a National Resource: Heritage Languages in the United States. Center for Applied Linguistics (Washington, DC), 2002.

Brecht, Richard, and William Rivers. Language and National Security in the 21st Century: The Role of Title VI/Fulbright Hayes in Supporting National Language Capacity. Kendall/Hunt, 2000.

Brown, Alan. "Less Commonly Taught Language and Commonly Taught Language Students: A Demographic and Academic Comparison." Foreign Language Annals, vol. 42 , no. 3, 2009, pp. 405-23.

Caballero, Ana. "Preparing Teachers to Work with Heritage Language Learners." Handbook of Heritage, Community and Native American Languages in the United States, edited by Terrence Wiley et al., Routledge/CAL, 2014, pp. 359-69.

Česká škola bez hranic. www.csbh.cz. Accessed 25 Sept. 2016.

Chevalier, Joan. "Heritage Language Literacy: Theory and Practice." Heritage Language Journal, vol. 2, no.1, 2004, pp. 26-44.

Čmejrková, Světla. Čeština, jak ji znáte i neznáte. Academia, 1996.

Carreira, Maria, and Olga Kagan. "The Results of the National Heritage Language Survey: Implications for Teaching, Curriculum Design, and Professional Development.” Foreign Language Annals, vol. 43, no. 3, 2011, pp. 40-64.

Danaher, David. "Audience." Edited by Václav Havel. cokdybysme.net/syllabimaterials.html. Accessed 7 Oct. 2016.

De Groot, Casper. "The Grammars of Hungarian Outside Hungary from a Linguistic Typological Perspective." Hungarian Language Contact Outside Hungary: Studies on Hungarian As a Minority Language, edited by Anna Fenyvesi, John Benjamins, 2005, pp. 351-70.

Deligiannidou, Anna. "To Travel Is to Love." Questgarden, questgarden.com/166/24/9/140104064434/index.htm. Accessed 7 Oct. 2016. 
Dengub, Evgeny. "Investigating Syntactic and Lexical Complexity, Accuracy, and Fluency in the Writing of Heritage Speakers of Russian." Dissertation, Bryn Mawr College, 2012.

"Dissertations with a Heritage Language Focus 2006-2015." http://www.international.ucla.edu/media/files/Bibliographies_2015.pdf. Accessed 7 Oct. 2016.

Dubinina, Irina. "How to Ask for a Favor: An Exploration of Speech Act Pragmatics in Heritage Russian." Dissertation, Bryn Mawr College, 2012.

Dubinina Irina, and Maria Polinsky. "Russian in the USA." Slavic Languages in Migration, edited by Michael Moser. University of Vienna, 2013.

Eisen, Samuel. "The Language Flagship Model and the Humanities." Russian Language Journal, vol. 64, 2014, pp. 5-24.

Evans-Romaine, Karen, et al. "Language and Cultural Learning Through Song: Three Complementary Contexts." The Art of Teaching Russian, edited by Evgeny Dengub, Irina Dubinina and Jason Merrill, Slavica, 2017.

Fenyvesi, Anna, editor. Hungarian Language Contact Outside Hungary: Studies in Hungarian as a Minority Language. Benjamins, 2005.

Friedman, Deborah, and Olga Kagan. "Academic Writing Proficiency of Russian Heritage Speakers." Heritage Language Education: A New Field Emerging, edited by Donna Brinton, Olga Kagan and Susan Bauckus, Routledge, 2008, pp. 181-98.

Gagarina, Natalia. "The Acquisition of Aspectuality by Russian Children: The Early Stages." ZAS Papers in Linguistics, vol. 15, 2000, pp. 232-46.

---. "Verbs of Motion in Russian: An Acquisitional Perspective." Slavic and East European Journal, vol. 53, no. 3, 2009, pp. 351-70.

Gardner, Robert. Social Psychology and Second Language Learning: The Role of Attitudes and Motivation. E. Arnold, 1985.

Gasiński, T.Z. "English Elements in the Speech of the Croatian Immigrant Community of Santa Clara Valley, California." Zbornik Matice srpske za filologiju i lingvistiku, vol. 29, no. 2, 1986, pp. 31-45.

Geisherik, Anna. "The Role of Motivation Among Heritage and Non-Heritage Learners of Russian." Canadian Slavonic Papers, vol. 46, no. 1-2, 2004, pp. 9-22.

---. "Aspects of Teaching Literacy to Heritage Learners of Russian." Dissertation, Stony Brook University, 2005.

Goldberg, David, et al. "Enrollments in Languages Other Than English in United States Institutions of Higher Education, Fall 2013." MLA, Feb. 2015, www.mla.org/pdf/2013_enrollment_survey.pdf. Accessed 25 Sept. 2016.

Gregory, Gayle, and Carolyn Chapman. Differentiated Instructional Strategies: One Size Does Not Fit All. Corwin Press, 2002.

Heller, Monica. "Globalization, the New Economy, and the Commodification of Language and Identity." Journal of Sociolinguistics, vol. 7, no. 4, 2003, pp. 473-92.

---. Paths to Post-Nationalism: A Critical Ethnography of Language and Identity. Oxford UP, 2011.

Henzl, Vera. "The Cultivation and Maintenance of Literary Czech by American Speakers." Dissertation, Stanford University, 1975.

Howard, Kathryn, et al. "Who Studies Which Language and Why? A Cross-Language Survey of First-Year College-Level Language Learners." Journal of the National Council of Less Commonly Taught Languages, vol. 7, 2009, pp. 1-44. 
Hronek, Jiří. Obecná čeština. Charles University, 1972.

Isurin, Ludmila, and Tanza Ivanova-Sullivan. "Lost in Between: The Case of Russian Heritage Speakers.” Heritage Language Journal, vol. 6, no. 2, 2008, pp. 72-104.

Janda, Laura. "Teaching Advanced Czech: A Student-Driven Internet-Powered Course." Between Texts, Languages and Cultures: A Festschrift for Michael Henry Heim, edited by Craig Cravens, Masako Fidler and Susan Kresin, Slavica, 2008, pp. 7-15.

Jensen, Linda, and Lorena Llosa. "Heritage Language Reading in the University: A Survey of Students' Experiences, Strategies and Preferences." Heritage Language Journal, vol. 5, no. 1, 2007, pp. 98-116.

Jevgjovikj, Maja. "Understanding Heritage Language Ties in Balkan Families." Dissertation, Mills College, 2013.

Kagan, Olga. "In Support of a Proficiency-Based Definition of Heritage Language Learners: The Case of Russian." International Journal of Bilingual Education, vol. 8, no. 2-3, 2005, pp. 213-21.

---. "Intercultural Competence of Heritage Language Learners: Motivation, Identity, Language Attitudes, and the Curriculum." Proceedings of the Second Intercultural Competence Conference, University of Arizona, vol. 2, pp. 72-84.

---. “Russian Heritage Language Learners: From Students' Profiles to Project-Based Curriculum." Handbook of Heritage, Community and Native American Languages in the United States, edited by Terrence Wiley et al., Routledge, 2014, pp. 177-85.

Kagan, Olga, and Kathleen Dillon. "A New Perspective on Teaching Russian: Focus on the Heritage Learner." Heritage Language Journal, vol. 1, no. 1, 2003, pp. 76-90.

Kagan, Olga, and Susan Kresin. "Czech Emigration and Czech Heritage: Implications for Teaching." Between Texts, Languages and Cultures: A Festschrift for Michael Henry Heim, edited by Craig Cravens, Masako Fidler and Susan Kresin, Slavica, 2008, pp. 109-20.

Kagan, Olga, and Anna Kudyma. Writing in Russian for Russian Heritage Speakers. Zlatoust, 2011.

Karkafi, Larisa. "Negative Language Transfer: A Study of Essays by Heritage and L2 Students of Russian at the Intermediate Mid Level of Proficiency." Dissertation, University of California, Los Angeles, 2014.

Kasatkina, Natalia. "Analyzing Language Choice Among Russian-Speaking Immigrants to the United States." Dissertation, University of Arizona, 2010.

Kondo-Brown, Kimi. "Heritage Language Instruction for Post-Secondary Students from Immigrant Background." Heritage Language Journal, vol. 1, no. 1, 2004, pp. $1-25$.

Kradinova, Larisa. “What's Preached' vs. 'What's Practiced': Language Views and Family Language Practices in Russian-English Bilingual Families." Dissertation, University of Arizona, 2007.

"Krajané." Ministerstvo zahraničních věcí, www.mzv.cz/jnp/cz/zahranicni_vztahy/krajane/index.html. Accessed 25 Sept. 2016.

Kramer, Christina. "Accommodating Dialect Speakers in the Classroom: Sociolinguistic Aspects of Textbook Writing." Canadian Slavonic Papers, vol. 46, no. 1-2, 2005, pp. 59-72. 
Krashen, Stephen. Principles and Practice in Second Language Acquisition. PrenticeHall, 1987.

---. Free Voluntary Reading. Libraries Unlimited, 2011.

Kuehnast, Milena. "Processing Negative Imperatives in Bulgarian: Evidence from Normal, Aphasic and Child Language." Dissertation, University of Potsdam, 2010.

---. "Acquisition of Negative Imperatives in Bulgarian-Implications for Verbal Aspect." Tense, Aspect and Mood in First and Second Language Acquisition, edited by Emanuelle Labeau and Ines Saddour, Rodopi, 2012, pp. 27-54.

"Kurz češtiny pro krajany", ÚJOP, ujop.cuni.cz/kurz/kurz-cestiny-prokrajany?from $=7$. Accessed 25 Sept. 2016.

Laleko, Oksana. "The Syntax-Pragmatics Interface in Language Loss: Covert Restructuring of Aspect in Heritage Russian." Dissertation, University of Minnesota, 2010.

---. "Assessing Heritage Language Vitality: Russian in the United States." Heritage Language Journal, vol. 10, no. 3, 2013, pp. 382-95.

---. "Restructuring of Verbal Aspect in Heritage Russian: Beyond Lexicalization." International Journal of Language Studies, vol. 5, no. 3, 2011, pp. 13-26.

“Language Enrollment Database, 1958-2013," MLA, www.mla.org/flsurvey search. Accessed 25 Sept. 2016.

Lauersdorf, Mark. "Training Teachers of Slavic LCTLs: Student Profiles and Program Design." The Learning and Teaching of Slavic Languages and Cultures, edited by Olga Kagan and Benjamin Rifkin, Slavica, 2000, pp. 497-518.

Leisiö, Larisa. "Genitive Subjects and Objects in the Speech of Finland Russians." Journal of Slavic Linguistics, vol. 14, no. 2, 2006, pp. 289-316.

Liu, Jac, and Setsue Shibata. "Why College Students Want to Learn Asian Languages: A Comparative Study of Motivational Factors for the Selection of Chinese, Japanese, Korean and Vietnamese." Journal of the National Council of Less Commonly Taught Languages, vol. 5, 2008, pp. 33-55.

Liu, Na, et al. Challenges and Needs of Community-Based Heritage Language Programs and How They Are Addressed. Center for Applied Linguistics (Washington DC.), 2011.

Lo Bianco, Joseph, and Joy Peyton. "Vitality of Heritage Languages in the United States: The Role of Capacity, Opportunity, and Desire." Heritage Language Journal, vol. 10, no. 3, 2013, pp. i-viii.

Lynch, Andrew. "The First Decade of the Heritage Language Journal: A Retrospective View of Research on Heritage Language." Heritage Language Journal, vol. 11, no. 3, 2014, pp. 224-42.

Lyskawa, Paulina. Variation in Case Marking in Heritage Polish. Heritage Language Variation and Change Project, University of Toronto, 2015.

Lyutykh, Elena. "Russian Language Schools: Exploring Heritage Literacy Beliefs and Practices in Families, Instruction, and Communities." Dissertation, Northern Illinois University, 2011.

Malone, Margaret, et al. "Assessment of Heritage Language Learners: Issues and Directions." Handbook of Heritage, Community and Native American Languages in the United States, edited by Terrence Wiley et al., Routledge, 2014, pp. 349-58. 
Marteijn, Wendy, and Chr. Sg. Walcheren "Across the Barricades." Questgarden, questgarden.com/15/79/6/060206080007/process.htm. Accessed 7 Oct. 2016.

McCabe, Marta. "Parental Experiences with Children's Heritage Language Maintenance and Loss: Cases of Eleven Czech and Slovak Transnational Immigrant Families in the Southeastern United States." Dissertation, University of North Carolina, 2014.

Mikhaylova, Anna. "(In)complete Acquisition of Aspect in Second Language and Heritage Russian." Dissertation, University of South Carolina, 2012.

Moore, Ekaterina. "Language and Social Identity Construction: A Study of a Russian Heritage Language Orthodox Christian School." Dissertation, University of California, Los Angeles, 2012.

Moore, Sarah. "Program Models for Heritage Language Education." Handbook of Heritage, Community and Native American Languages in the United States, edited by Terrence Wiley et al., Routledge, 2014, pp. 359-69.

Murphy, Dianna, et al. "Reasons Students Take Courses in Less Commonly Taught Languages." Journal of the National Council of Less Commonly Taught Languages, vol. 7, 2009, pp. 45-80.

Nemtchinova, Ekaterina. "Developing Information Literacy Skills in the Beginning Language Classroom: A Case for WebQuests." Russian Language Journal, vol. 64, 2014, pp. 83-110.

Nyikos, Martha, and Vesna Dimitrieska. "A Model for Community-Based Language Teaching to Young Learners: The Impact of University Outreach." Journal of the National Council of Less Commonly Taught Languages, vol. 17, 2015, pp. 83-102.

Paternost, Joseph. "Slovenian Language in Minnesota's Iron Range: Some Sociolinguistic Aspects of Language Maintenance and Language Shift." General Linguistics, vol. 16, 1976, pp. 95-150.

Pavlenko, Aneta. "Bilingualism and Emotion." Multilingua, vol. 21, 2002, pp. 45-78.

Pereltsvaig, Asya. "Aspect in Russian As Grammatical Rather Than Lexical Notion: Evidence from Heritage Russian." Russian Linguistics, vol. 32, no. 1, 2008, pp. 2742.

Petrescu, Maria. "Minority Language Acquisition and Retention: A Study of CanadianBorn Romanian-Speaking Bilingual Children." Dissertation, University of Toronto, 2014.

"A Pirate on the Danube," Commenius Project, comenius-danubelifeline.eu/hp725/Webquest-for-students.htm. Accessed 7 Oct. 2016.

Pires, Acrisio, and Jason Rothman. "Disentangling Sources of Incomplete Acquisition: An Explanation for Competence Divergence Across Heritage Grammars." International Journal of Bilingualism, vol. 13, no. 2, 2009, pp. 211-38.

"Podpora výuky češtiny v zahraničí z pohledu MZV," csbh.cz/sites/default/files/Podpora_vyuky_cestiny_v_zahranic_z_pohledu_MZV _.pdf. Accessed 25 Sept. 2016.

Polinsky, Maria. “Cross-Linguistic Parallels in Language Loss." Southwest Journal of Linguistics, vol. 14, no. 1-2, 1995, pp. 88-123.

---. "Heritages Languages and Their Speakers: State of the Field, Challenges, Perspectives for Future Work, and Methodologies." Zeitschrift fuer Fremdsprachwissenschaft, vol. 26, 2015, pp. 7-27. 
---. “Incomplete Acquisition: American Russian." Journal of Slavic Linguistics, vol. 14, no. 2, 2006, pp. 191-262.

---. "Russian Gender Under Incomplete Acquisition: Heritage Speakers' Knowledge of Noun Categorization." Heritage Language Journal, vol. 6, no. 1, 2008, pp. 4071.

Polinsky, Maria, and Olga Kagan. "Heritage Languages: In the 'Wild' and in the Classroom." Languages and Linguistics Compass, vol. 1, no. 5, 2007, pp. 368-97.

Potowski, Kim. Language and Identity in a Dual Immersion School. Multilingual Matters, 2007.

Potowski, Kim, et al. "Teachers of Heritage Language Speakers: Perturbing Assumptions and Possible Solutions." Expanding Our Horizons: Language Teacher Education in the 21st Century, edited by Elaine Tarone and Dan Soneson, University of Minneapolis Center for Advanced Research on Language Acquisition, 2013, pp. 19-46.

Preston, Dennis, and Michael Turner. "The Polish of Western New York: Case." The Slavic Languages in Émigré Communities, by Roland Sussex, Linguistic Research Inc., 1984, pp. 134-54.

Rechcigl, Miloslav. Czech-American Bibliography: A Comprehensive Listing with Focus on the US and with Appendices on Czechs in Canada and Latin America. AuthorHouse, 2011.

Šabec, Nada. "Language Maintenance Among Slovene Immigrants in the United States." Slovene Studies, vol. 15, no. 1-2, 1993, pp. 151-68.

Seals, Corinne. "Multilingual Identity Development and Negotiation Amongst Heritage Learners: A Study of East European-American Schoolchildren in the United States.” Dissertation, Duke University, 2013.

Seals, Corinne, et al. "Dissertation and Thesis Abstracts on Heritage Education 20002012." Center for Applied Linguistics, www.cal.org/heritage/pdfs/dissertation/heritage-language-educationdissertation-and-thesis-abstracts.pdf. Accessed 7 Oct. 2016.

Seymour-Jorn, Caroline. "Arabic Language Learning Among Arab Immigrants in Milwaukee, Wisconsin: A Study of Attitudes and Motivations." The Journal of Muslim Minority Affairs, vol. 24, no. 1, 2005, pp. 109-22.

Shekhman, Boris, and Betty Lou Leaver. "Developing Professional-Level Language Proficiency: The Shekhman Method of Communication." Developing ProfessionalLevel Language Proficiency, edited by Betty Lou Leaver and Boris Shtekhtman, Cambridge UP, 2002, pp. 119-40.

The Slavic Languages in Émigré Communities. Linguistic Research Inc., 1981.

Slegrova, Gabriela. "A Trip to Prague." Questgarden, questgarden.com/170/49/7/140419092919/index.htm. Accessed 7 Oct. 2016.

Smyslova, Alla. "Developing Four-Skill Literacy Among Adult Heritage Learners: Effects of Linguistic and Non-Linguistic Variables on the Attainment of LowProficiency Heritage Students of Russian Within a Dedicated College-Level Bridge Course." Dissertation, Bryn Mawr College, 2009.

---. "Low Proficiency Heritage Speakers of Russian: Comparing Effects of Instructional Intervention on Language Skills Development in Heritage and NonHeritage Learners of Russian." Mnemosynon. Studies on Language and Culture in 
the Russophone World, edited by Richard Brecht et al., Azbukovnik, 2009, pp. 211-27.

Stoll, Sabine. "The Acquisition of Russian Aspect." Dissertation, University of California, Berkeley, 2001.

Sussex, Roland. "Slavonic Languages in Emigration." The Slavonic Languages, edited by Bernard Comrie and Gerald Corbett, Routledge, 1993, pp. 999-1036.

---, editor. The Slavic Languages in Émigré Communities. Linguistic Research Inc., 1981.

Tamošiūnaitè, Aurelija. "Lithuanian Saturday Schools in Chicago: Student Proficiency, Generational Shift, and Community Involvement." Heritage Language Journal, vol. 10, no. 1, 2013, pp. 108-33.

"Teaching Heritage Languages." Startalk, startalk.nhlrc.ucla.edu/startalk/lessons.aspx. Accessed 7 Oct. 2016.

Tomlinson, Carol. The Differentiated Classroom: Responding to the Needs of All Learners. Association for Supervision and Curriculum Development, 1999.

Townsend, Charles. A Description of Spoken Prague Czech. Slavica, 1990.

Trifonas, Peter, and Themistoklis Aravossitas, editors. Rethinking Heritage Language Education. Cambridge UP, 2014.

Valdés, Guadalupe. "The Teaching of Minority Languages As 'Foreign' Languages: Pedagogical and Theoretical Challenges." Modern Language Journal, vol. 79, no. 3, 1995, pp. 299-328.

---. "The Teaching of Heritage Languages: An Introduction for Slavic Teaching Professionals." The Learning and Teaching of Slavic Languages and Cultures, edited by Olga Kagan and Benjamin Rifkin, Slavica, 2000, pp. 375-403.

Van Deusen-Scholl, Nelleke. "Toward a Definition of Heritage Language: Sociopolitical and Pedagogical Considerations." Journal of Language, Identity, and Education, vol. 2, no. 3, 2000, pp. 211-30.

---. "Research on Heritage Language Issues." Handbook of Heritage, Community and Native American Languages in the United States, edited by Terrence Wiley et al., Routledge/CAL, 2014, pp. 76-84.

---. "Ve světě roste počet českých škol." Deník, 24 Aug. 2012, www.denik.cz/z domova/ve-svete-roste-pocet-ceskych-skol-vzdelani-jerovnocenne-s-ceskym-20120824.html. Accessed 25 Sept. 2016.

Weist, Richard, et al. "The Defective Tense Hypothesis: On the Emergence of Tense and Aspect in Child Polish." Journal of Child Language, vol. 11, no. 2, 1984, pp. 347-74.

Wiley, Terrence, et al. Handbook of Heritage, Community and Native American Languages in the United States. Routledge/CAL, 2014.

Zemskaja, Elena, and Marina Glovinskaja. Jazyk russkogo zarubežja: Obščie procesy $i$ rečevyje portrety. Jazyki slavjanskoj kul'tury, Moscow, 2001. 